\title{
Comparison of sensitivity of three legume species exposed to crude extracts of toxic and non-toxic cyanobacteria
}

\author{
So sánh độ nhạy cảm của ba loại cây ho đậu khi phơi nhiếm với ly trích vi \\ khuẩn lam chứa độc tố và không chứa độc tố microcystins \\ Research article
}

Thanh Luu Pham*

Institute of Tropical Biology, Vietnam Academy of Science and Technology (VAST), 85 Tran Quoc Toan St., District 3, Ho Chi Minh City, Vietnam

\begin{abstract}
We evaluated the effect of cyanobacterial crude extracts containing microcystin (CCEMC+) from a natural bloom on seed germination and initial development of three economically important legume species: green mung bean Vigna radiata, cowpea Vigna cylindrical and red mung bean Vigna angularis and compared it to crude extracts of cyanobacteria without the toxin (CCEMC-). Results showed that CCEMC+ and CCEMC- caused different effects on seed germination and initial development of the three species. There was a clear inhibition on germination and root growth of the green mung bean exposed to the CCEMC $+(20,200$ and $500 \mu \mathrm{g} / \mathrm{L})$, indicating that the green mung bean being more sensitive to CCEMC + when compared to the cowpea and red mung bean. CCEMC + induced a greater occurrence of abnormal seedlings in the green mung bean, duce to inhibition the germination as well as reduction of fresh weight and root length. The CCEMC- extract caused no harmful effects to germination and seedlings growth of the green mung bean and red mung bean. However, it reduced shoot and root length in cowpea bean, suggesting that the cowpea being more sensitive to both extracts. Our results indicated that the sensitivity in germination and root growth of the green mung bean $V$. radiata could be used as an indicator to evaluate the toxic effect and monitor the toxin concentration of water contaminated with microcystins.
\end{abstract}

Nghiên cứu này khảo sát và so sánh các tác động bất lọi của ly trích vi khuẩn lam có chía và không chưa độc tố lên sư nẩy mầm và sự phát triển ở giai đoạn đầu của ba loại cây ho đậu gồm đậu xanh Vigna radiata, đậu đỏ Vigna angularis và đậu đen Vigna cylindrical. Kết quả cho thấy hai loại ly trích gây ra các tác động khác nhau lên ba loại cây đậu thí nghiệm. Ly trích vi khuẩn lam có chứa độc tố ở nồng độ 20, 200 và $500 \mu \mathrm{g} / \mathrm{L}$ ngăn chăn đáng kể sự nẩy mầm và sư phát triển rể ở đậu xanh. Cả hai loại ly trích có chứa và không chưa độc tổ đều ngăn chặn sư nẩy mầm và sư phát triển rể ở đậu đen. Ngược lai ly trích vi khuẩn lam có chứa độc tố ở nồng độ $500 \mu \mathrm{g} / \mathrm{L}$ lại kích thích chiều dài rể, thân mầm và trọng luợng tuơ ở đậu đỏ. Kết quả cho thấy đậu đen khá nhạy cảm với cả hai loại ly trích có chứa và không chưa độc tố, trong khi đó đậu xanh nhạy cảm hơn với ly trích có chưa độc tố. Tính nhay cảm của các loại cây ho đậu khi phơ nhiếm với ly trích vi khuẩn lam có thể được sủ dụng để chỉ thị cho sư ô nhiếm và quan trắc độc tố vi khuẩn lam trong môi truòng.

Keywords: Germination, sensitivity, cyanobacterial crude extract, microcystins, legume species bio-indicator 


\section{Introduction}

Cyanobacterial blooms are currently a worldwide problem due to the eutrophication of water bodies and climate change due to the ability to produce different cyanotoxins [1]. Among cyanotoxins, Microcystins (MCs) are the most commonly detected cyanotoxin in freshwater bodies. MCs normally exist inside cyanobacterial cells but they are released to the surrounding water after cell lysis especially at the end of bloom events. When water contaminated with cyanobacteria containing MCs is used as an irrigation source, it is possible for a large amount of MCs being contaminated and caused adverse effects on the cropland [1].

Previous studies have shown that MCs not only reduce the germination of seeds of aquatic plants but also affect agricultural plants, such as peas (Pisum sativum L.), lentils (Lens esculenta Moench), maize (Zea mays L.) and wheat (Triticum durum L.) [2, 3]. Furthermore, the toxin interferes with the metabolism of the seedlings [4], causing necroses $[5,6]$. However, previous studies have focused only on isolating MCs or using purified MCs [7] in toxicity studies. It should be noted that cyanobacteria produce several compounds other than cyanotoxins [8], the function of which is still unknown, as are their effects on plants. Although on aquatic community some organisms may suffer direct effects due to contact with these different compounds [1]. It would therefore be valuable to evaluate the effects of these complex cyanobacterial biomasses in irrigation water on the cropland.

Some terrestrial plants are sensitive to cyanotoxins as irrigation with water contaminated with cyanotoxins. Previous studies have shown that crude extracts of the cyanobacteria with MC and without MC caused different effects on seed germination and initial development of the salad green seedlings, and lettuce being more sensitive to both extracts when compared to arugula [9]. In addition Dao et al. (2014) [10] shown that the germination and seeding growth of some vegetables were damaged under exposure to microcystins contaminated water from the Dau Tieng reservoir. Agricultural plants showed differently response to cyanobacteria producing microcystins. Saqrane et al. (2008) [2] shown that cyanobacteria producing microcystins caused germination inhibition with dose dependent on Pisum sativum, Lens esculenta, Zea mays and Triticum durum. Pisum sativum showed the most sensitive with a $97 \%$ germination rate reduction while L. esculenta showed the most resistant to cyanobacteria producing microcystins.

Until now major focus of research is based on the effects of MCs on aquatic organisms especially aquatic animals but few have considered the effects of toxic and non-toxic CCE on terrestrial plants, and no study have suggested using terrestrial plants for monitoring or indicating MCs in the water environment. Considering the response of terrestrial plants to different toxic stressors, the identification of local plants that have ability to indicate these toxic stressors in irrigation water is a valuable piece of information. Thus, our objective was to compare the sensitivity on seed germination and seedling development and the adverse effect on the three economically important legume species: green mung bean Vigna radiata, black-eyed bean Vigna unguiculata, and adzuki bean Vigna angularis when exposed to the two crude extracts including microcystin-producing (CCEMC+) and non-microcystinproducing (CCEMC-).

\section{Materials and methods}

\subsection{Preparation of cyanobacterial crude extracts}

The toxic biomass of cyanobacterial bloom (mainly $M i$ crocystis) collected from the Dau Tieng Reservoir (Fig. 1a) and the non-toxic cyanobacteria Pseudanabaena isolated from the same location were used for the experiment (Fig. 1b). Bloom material was dried under sunlight and kept at $-20^{\circ} \mathrm{C}$ prior to extraction for the test. The nontoxic cyanobacteria Pseudanabaena sp. strain was isolated from the Dau Tieng Reservoir according to the methods reported by Pham et al. (2015) [12]. Briefly, a single cyanobacterial colony of Pseudanabaena sp. was isolated by micropipetting in several steps, washed, and transferred into vials containing Z8 medium. All cultures were grown on a $12 \mathrm{~h}: 12 \mathrm{~h}$ light:dark cycle at a temperature of $28^{\circ} \mathrm{C}$ under light intensity of $30 \mu \mathrm{mol}$ photons $/ \mathrm{m}^{2} \mathrm{~s}$. Biomasses of cultures were harvested onto GF/C glass fiber filters (Whatman, Kent, England) at the end of the exponential growth phase. The filters containing Pseudanabaena were dried at $45^{\circ} \mathrm{C}$ overnight and kept at $-20^{\circ} \mathrm{C}$ until the experiment.
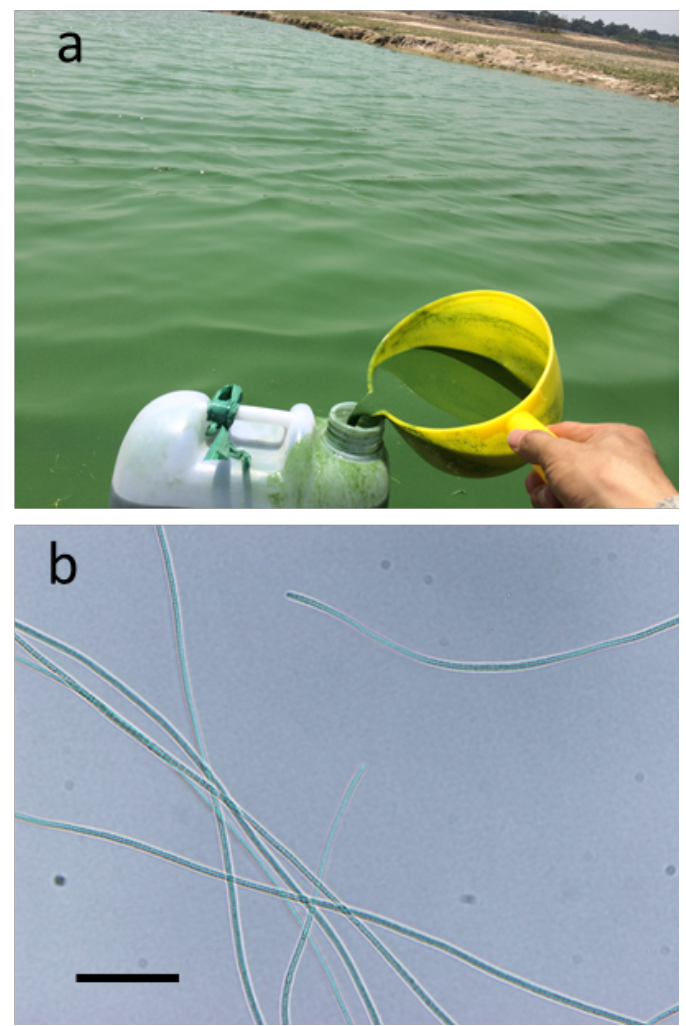

Figure 1. Collection of cyanobacterial bloom from the Dau Tieng Reservoir (a) and the non-toxic cyanobacteria Pseudanabaena (b) 
Cyanobacterial crude extracts (CCE) were prepared according to Pietsch et al. (2001) [11] with some modifications. Briefly, $2 \mathrm{~g}$ dry weight (DW) of the bloom material and Pseudanabaena (moisture content less than 10\%) were dissolved into distilled water, frozen at $-70^{\circ} \mathrm{C}$ then thawed at room temperature. After the materials were thawed completely, they were sonicated for 3 minutes. This freeze-thaw-sonicate cycle was repeated five times. The samples were then centrifuged at $2000 \times \mathrm{g}$ for 10 minutes to remove cell debris. The supernatant was collected and kept at $-20^{\circ} \mathrm{C}$ until use for the toxicity experiments. The concentration of $8 \mathrm{~g} / \mathrm{L}$ of cyanobacterial crude extract $(w / v)$ was prepared. Sub samples of the CCE supernatant were used for MC analysis as previously reported by Pham et al. (2015) [12]. Briefly, $100 \mu \mathrm{L}$ of the supernatants was centrifuged at $6000 \times \mathrm{g}$ at $4^{\circ} \mathrm{C}$ for $15 \mathrm{~min}$. The supernatant was collected, dried completely, and redissolved in $500 \mu \mathrm{L}$ of $100 \% \mathrm{MeOH}$. The samples were analyzed by HPLC system with UV-visible photodiode array (PDA) detector (Shimadzu 10A series, Kyoto, Japan). Purified MCs from Wako company (Osaka, Japan) were used as standards.

\subsection{Experiment design}

Seeds of green mung bean $V$. radiata, cowpea Vigna cylindrical and red mung bean $V$. angularis from Tam Nong company were used. For each treatment, three replicates of 30 seeds were sown randomly in petri dishes using $50 \mathrm{~g}$ sterile sand as substrate. The seeds were daily watered with $10 \mathrm{~mL}$ of toxic CCE containing $0,20,200$ and $500 \mu \mathrm{g} \mathrm{MC/L}$ (here after refer as: CTR, C20, C200, $\mathrm{C} 500)$ or the treatments with non-toxic CCE were prepared at the equivalent concentrations (here after refer as Non-toxic). The dishes were kept under constant conditions of light and temperature at $25 \pm 1{ }^{\circ} \mathrm{C}$ for seven days.

After seven days of cultivation, the germination percentages and the production of normal seedlings were recorded. The percentage of normal seedlings was calculated from the total number of germinated seeds. The length of the radicle and the shoot of seedlings were measured by using a ruler calibrated in millimetres. The seedlings were individually weighed using precision scales to obtain their fresh mass.

\subsection{Statistical analysis}

One-way analysis of variance (ANOVA) and Turkey test Post Hoc were applied for calculation of statistically differences of the fresh weight, shoot and radicle length of seedlings after the data checked for variance homogeneity and normality. All statistical analysis was done by using the Sigmaplot Version 12.0.

\section{Results}

\subsection{Microcystins concentration in the crude extracts}

The HPLC analysis showed that the bloom extract contained three MC variants (MC-RR, MC-LR and MC-YR), with a total concentration of $670 \mu \mathrm{g} \mathrm{MC} / \mathrm{g}$ dry weight (Fig. 2), whereas MC was not detected in the extract of Pseudanabaena. MC-RR was the most dominant variant in the bloom extract.

\subsection{Effects on germination}

During the exposed period, no inhibition of germination in the controls was observed. However, exposure to toxic CCEMC + showed different inhibition in germination depending on the sensitivity of each legume species tested (Table 1). The germination of the green mung bean $V$. radiate was affected greatly in the presence of CCEMC+ at dose dependence $(90 \%, 83 \%$ and $70 \%$ in $\mathrm{C} 20, \mathrm{C} 200$ and $\mathrm{C} 500$, respectively), while the germination of the cowpea $V$. cylindrical only reduced in the C500 treatment and the germination of the red mung bean $V$. angularis did not affected in any treatment. On the other hand, the low concentration of toxic CCE and the non-toxic CCE did not caused any effect on the germination of all species.

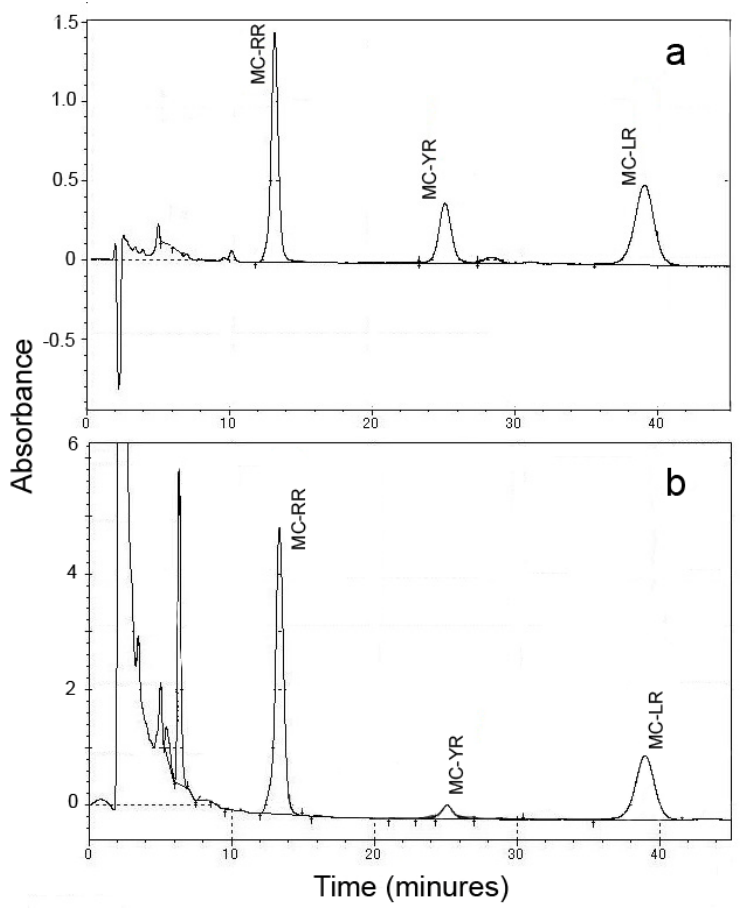

Figure 2. The HPLC chromatography of standards (a) and toxic cyanobacterial extract (b)

Table 1. Germination rate (\%) of the three legume species tested

Species

Exposures

\begin{tabular}{lccccc}
\cline { 2 - 6 } & CTR & Non-Toxic & C20 & C200 & C500 \\
\hline Vigna radiata & 100 & 100 & 90 & 83 & 70 \\
Vigna angularis & 100 & 100 & 100 & 100 & 100 \\
Vigna cylindrica & 100 & 100 & 100 & 100 & 80
\end{tabular}




\subsection{Effect on radicle and shoot length}

Toxic CCEMC+ and non-toxic CCEMC- showed different effects on the radicle and shoot length of tested species (Fig. 3). In green mung bean $V$. radiata the radicle and the shoot length was significantly reduced with dose dependence in CCEMC+ treatment but the CCEMC- (Fig. $3 \mathrm{a}, \mathrm{d})$. The CCEMC+ as well as CCEMC- also reduced significantly the radicle length and the shoot length of the cowpea $V$. cylindrical (Fig. 3c,f). On the other hand, CCEMC+ as well as CCEMC-did not reduced the radicle length and the shoot length of the red mung bean $V$. angularis, except the CCEMC+ at $500 \mathrm{MC} / \mathrm{L}$ significantly increased the radicle length and the shoot length (Fig. 3b, e).
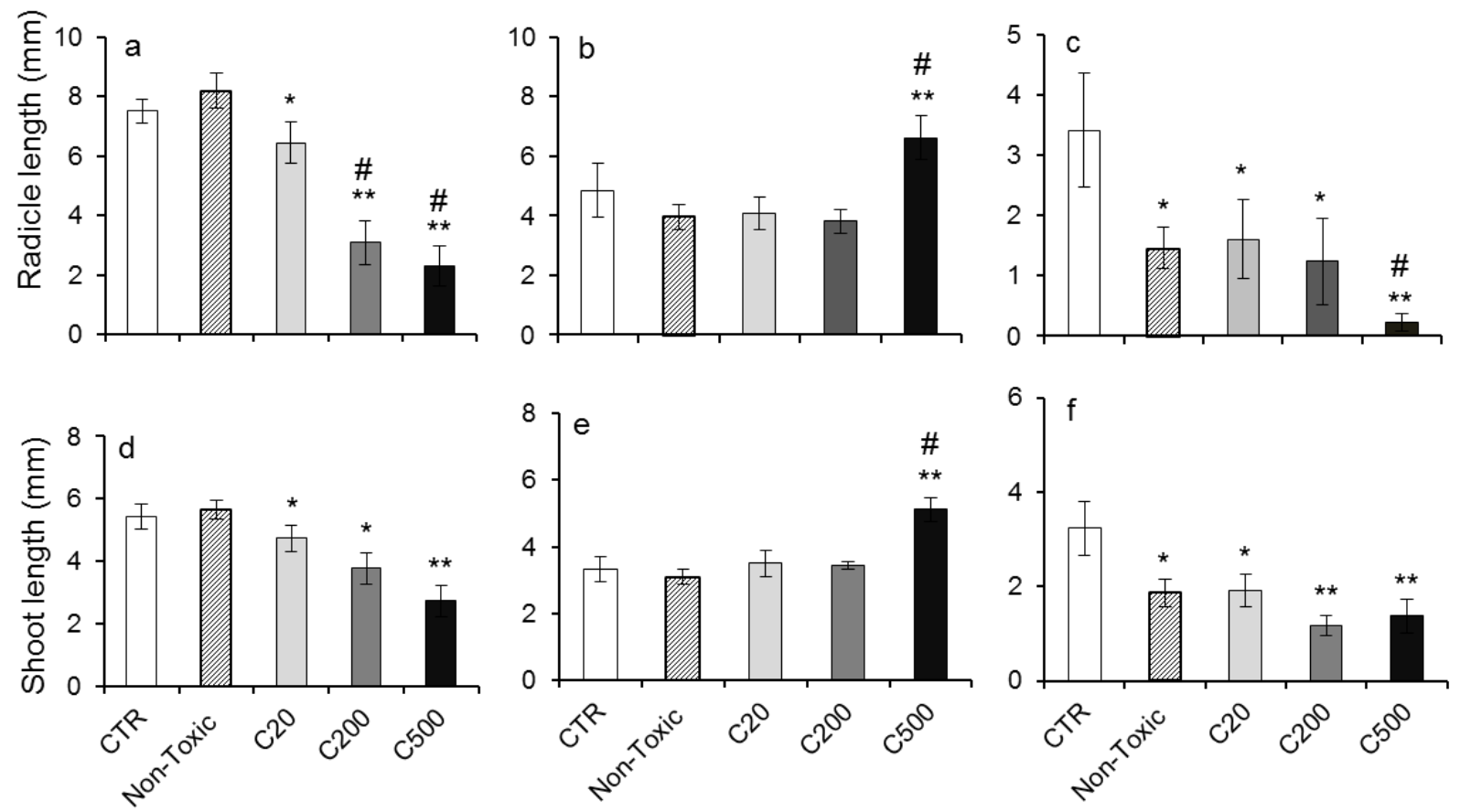

Figure 3. The radicle length and the shoot length of the seedlings (mean value \pm SD, $n=30)$ of (a,d) green mung bean Vigna radiate; (b,e) red mung bean Vigna angularis and (c,f) cowpea Vigna cylindrical

\subsection{Effect on fresh weight}

After 7 days of exposure, the fresh weight of three tested species was affected but in different ways (Fig. 4). While fresh weight of the green mung bean $V$. radiata was reduced significantly at high concentration of CCEMC+
(C200 and C500) (Fig. 4a), the fresh weight of the cowpea $V$. cylindrica reduced significantly in both toxic and non-toxic CCE treatments (Fig. 4c). In contrast the $\mathrm{CCEMC}+$ containing $500 \mu \mathrm{g} \mathrm{MC} / \mathrm{L}$ resulted in significantly increasing the fresh weight of the red mung bean $V$. angularis (Fig. 4b).
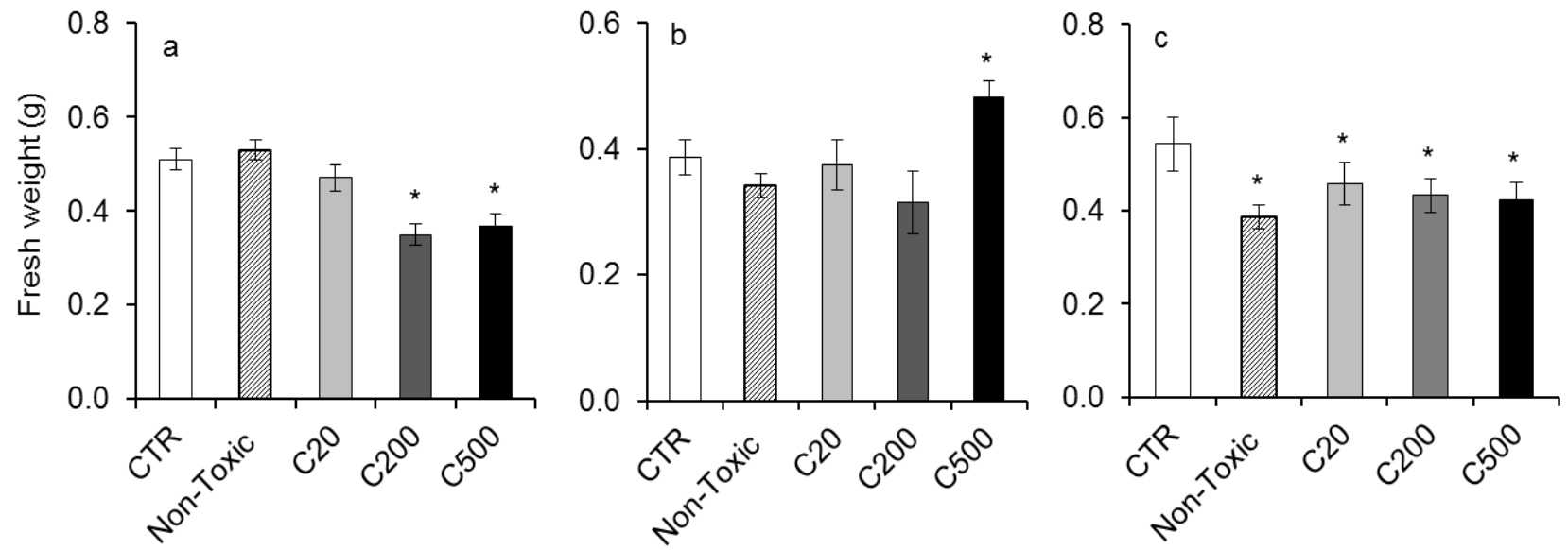

Figure 4. The fresh weight of the seedlings (mean value $\pm \mathrm{SD}, \mathrm{n}=30$ ) of (a) green mung bean Vigna radiate; (b) red mung bean Vigna angularis and (c) cowpea Vigna cylindrica 


\section{Discussion}

Previous studies of MCs affect in terrestrial plants have suggested MCs accumulation, inhibition of germination and decrease in growth. Our results clearly show that toxic and non-toxic CCE caused adverse effects on germination and seedling of legume species and the effects is species dependent, which can be related to the detoxification system of each species. In general the CCEMC+ caused stronger effects on tested species than the CCEMC- did. The most sensitivity with the CCEMC+ was the green mung bean $V$. radiate as higher the MCs concentration, the more the growth and seedling was inhibited. The cowpea $V$. cylindrica showed sensitively with both toxic and non-toxic CCE, while the red mung bean $V$. angularis showed no effects or even stimulating at high concentration of toxic CCE. The adverse effects obtained in the present study are similar to those reported for other terrestrial plants cultured in vitro. For example, the growth and development of rapeseed Brassica napus, apple Malus pumila and rice Oryza sativa seedling were inhibited after exposure to MCs during 4 days (B. napus and $O$. sativa) and 14 days (M. pumila) $[5,13,14]$. The same results were reported for Solanum tuberosum and Ceratophyllum demersum after their exposure to $5 \mu \mathrm{g} / \mathrm{mL}$ MCs during 16 days and 24 hours respectively [15]. Furthermore, Mathé et al. (2007) [16] studied the effect of pure MC-LR on the growth and histology of common reed Phragmites australis cultured in vitro for 35 days. The authors observed the inhibition of the growth of shoot and root parts, histological alterations, brownish aspect, necrosis and tissue lysis. MC-LR at the concentration of 2.5-80 $\mu \mathrm{g} / \mathrm{mL}$ have also caused toxic effects on the growth, biomass accumulation, blocked root hairs formation and root tips exhibited necrosis in faba bean Vicia faba seedling cultured in vitro [17]. The toxic effects of MCs on the germination and seedling of terrestrial plants are due to the inhibition of protein phosphatase and photosynthesis in leaves $[18,19]$. However, plants can be detoxified MCs by a mechanism of conjugation with glutathione [15]. As the molecule of MC is highly stable, and may persist in plant tissues until consumption, this process, in addition to fostering production of plants, reduces the poisoning of consumers. This is suitable for the explanation the promotion in the length of root and seedlings of the red mung bean $V$. angularis.

Our results we also confirmed the toxic effects of nontoxic cyanobacterial extracts on terrestrial plant. These toxic effects may cause by other compounds present in the extracts without MC equivalent. Another important toxic compound produced by cyanobacteria is the lipopolysaccharides (LPSs) also known as lipoglycans and endotoxins. They are large molecules consisting of a lipid and a polysaccharide composed of $\mathrm{O}$-antigen, outer core and inner core joined by a covalent bond; they are found in the outer membrane of all cyanobacteria, and elicit strong immune responses in animals [20]. Cyanobacterial LPS is attributed with a range of pathological effects in animal and humans, from cutaneous signs and symptoms, gastro-intestinal illness, respiratory disease, allergy, headache and fever [20, 21]. Results of the present study demonstrated that even a cyanobacteria non-cyanotoxins- producing may generate toxic effects in terrestrial plants such as legume species.

Terrestrial and aquatic plants have been used for risk assessment of cyanotoxins in aquatic ecosystems [22, 23]. Several plant-based indices have been developed and successfully applied worldwide, especially indicative of urban and suburban pollution [24]. In this study red mung bean $V$. angularis was the most tolerant species to CCE exposure and other species such as green mung bean $V$. radiate and cowpea $V$. cylindrica were relatively more sensitive. Water pollution contains not only organic substances, but also natural and man-made toxic compounds. And our results showed that legume species showed rapidly response to various concentrations of cyanotoxins as well as other non-toxic compounds. And they could be used as a potential tool for indicating cyanotoxins contamination in aquatic ecosystems.

\section{Conclusions}

We found differences in sensitivity between legume species, being red mung bean less sensitive than green mung bean and cowpea. The extract of toxic cyanobacteria caused more harmful effects than the non-toxic one. The non-toxic extracts also affected the development of tested species, although to a lesser extent than the toxic one, showing that other substances produced by cyanobacteria may also affect the development of plants. The use of irrigation water contaminated with MCs may exert a negative biochemical effect on the germination of agricultural plants and in the metabolism of seedlings thereby reducing their productivity.

Acknowledgements: This research was founded by Vietnam National Foundation for Science and Technology Development (NAFOSTED) under grant number "106NN.04-2015.72”.

\section{References}

[1] Romero-Oliva C.S., Contardo-Jara V., Block T. and Pflugmacher S. (2014). Accumulation of microcystin congeners in different aquatic plants and crops A case study from lake Amatitlán, Guatemala. Ecotoxicology and Environmental Safety 102: 121-128.

[2] Saqrane S., El Ghazali I., Oudra B., Bouarab L. and Vasconcelos V. (2008). Effects of cyanobacteria producing microcystins on seed germination and seedling growth of several agricultural plants. Journal of Environmental Science and Health. Part. B, Pesticides, Food Contaminants, and Agricultural Wastes, 43(5): 443-451.

[3] Hereman TC. and Bittencourt-Oliveira MC. (2012). Bioaccumulation of microcystins in lettuce. Journal of Phycology, 48(6): 1535-1537.

[4] Saqrane S., Ouahid Y., El Ghazali I., Oudra B., Bouarab L. and del Campo FF. (2009). Physiological changes in Triticum durum, Zea mays, Pisum sativum and cultivars, caused by irrigation with water contaminated with microcystins: a laboratory experimental approach. Toxicon, 53(7-8): 786-796. 
[5] Chen J., Song L., Dai J., Gan N., Liu Z. (2004). Effects of microcystins on the growth and the activity of superoxide dismutase and peroxidase of rape (Brassica napus L.) and rice (Oryza sativa L.). Toxicon, 43: 393-400.

[6] M-Hamvas, M., Máthé, C., Molnár, E., Vasas, G., Grigorszky, I. and Borbely, G. (2003). MicrocystinLR alters the growth, anthocyanin content and single-stranded DNase enzyme activities in. Sinapis al$b a$ L. seedlings. Aquatic Toxicology (Amsterdam, Netherlands), 62(1): 1-9.

[7] Freitas M., Azevedo J., Pinto E., Neves J., Campos A. and Vasconcelos V. (2015). Effects of microcystin-LR, cylindrospermopsin and a microcystinLR/cylindrospermopsin mixture on growth, oxidative stress and mineral content in lettuce plants ( $\mathrm{Lac}$ tuca sativa L.). Ecotoxicology and Environmental Safety 116: 59-67.

[8] Pham T.-L., Shimizu K., Kanazawa A., Gao Y., Dao T.-S. and Utsumi M. (2016). Microcystin accumulation and biochemical responses in the edible clam Corbicula leana P. exposed to cyanobacterial crude extract. Journal of Environmental Sciences 44: 120130.

[9] Bittencourt-Oliveira M., Hereman T., Macedo-Silva I., Cordeiro-Araújo M., Sasaki F. and Dias C. (2015). Sensitivity of salad greens (Lactuca sativa L. and Eruca sativa Mill.) exposed to crude extracts of toxic and non-toxic cyanobacteria. Brazilian Journal of Biology 75: 273-278.

[10] Dao T.S., Le T.H., Pham T.L., Do-Hong L.C. (2014). Germination and seedling growth of Brassica juncea and Medicago sativa under exposure to microcystins-contaminated water from Dau Tieng Reservoir. Vietnamese Science \& Techonology Development Journal, 17 (M2): 33-42.

[11] Pietsch C., Wiegand C., Ame M. V., Nicklisch A., Wunderlin D., Pflugmacher S. (2001). The effects of cyanobacterial crude extract on different aquatic organisms: Evidence for cyanobacterial toxin modulating factors. Environmental Toxicology 16: 535-542.

[12] Pham T.L., Dao T.S., Shimizu K., Do-Hong L.C., Utsumi M. (2015). Isolation and characterization of microcystin-producing cyanobacteria from Dau Tieng Reservoir, Vietnam. Nova Hedwigia, 101(12): $3-20$.

[13] Chen J., Dai J., Zhang H., Wang C., Zhou G., Han Z., Liu Z. (2010). Bioaccumulation of microcystin and its oxidative stress in the apple (Malus pumila). Ecotoxicology, 19: 796-803.
[14] Chen J., Han F.X., Wanga F., Zhang H.,Shi Z. (2012). Accumulation and phytotoxicity of microcystin-LR in rice (Oryza sativa). Ecotoxicology and Environmental Safety, 76: 193-199.

[15] Pflugmacher S. (2002). Possible allelopathic effects of cyanotoxins, with reference to microcystin-LR, in aquatic ecosystems. Environmental Toxicology, 17: 407-413.

[16] Mathé C., M-hamvas M., Vasas G., Suranyi G., Bacsi I., Beyer D., Toth S., Timar M., Borbely G. (2007). Microcystin-LR, a cyanobacterial toxin, induces growth inhibition and histological alterations in common reed (Phragmites australis) plants regenerated from embryogenic calli. New phytologist, 176: 824-834.

[17] Majida L., Khalid O., Fatima E.K., Eloisa P., and Brahim O. (2015). Impact of cyanobacterial toxins (microcystins) on growth and root development of in vitro Vicia faba cultures. International Journal of Innovation and Applied Studies. 12(3): 542-551.

[18] Abe T., Lawson T., Weyers J.D.B., Codd G.A. (1996). Microcystin-LR inhibits photosynthesis of Phaseolus vulgaris primary leaves: implications for current spray irrigation practice. New Phytologist. 133: 651-658.

[19] McElhiney J., Lawton L.A., Leifert C. (2001). Investigations into the inhibitory effects of microcystins on plant growth, and the toxicity of plant tissues following exposure. Toxicon, vol. 39: 1411-1420.

[20] Best J.H., Pflugmacher S., Wiegand C., Eddy F.B., Metcalf J.S. and Codd G.A. (2002). Effects of enteric bacterial and cyanobacterial lipopolysaccharides, and of microcystin-LR, on glutathione S-transferase activities in zebra fish (Danio rerio). Aquatic Toxicology 60(3-4): 223-231.

[21] Hitzfeld B.C., Hoger S.J. and Dietrich D.R. (2000). Cyanobacterial toxins: removal during drinking water treatment, and human risk assessment. Environ Health Perspect 108 (Suppl 1): 113-122.

[22] Meyer, W.S. and Green, G.C. (1981). Plant indicators of wheat and soybean crop water stress. Irrigation Science 2(3):167-176.

[23] Bibo L., Yan G., Bangding X., Jiantong L. and Yongding L. (2008). A laboratory study on risk assessment of microcystin-RR in cropland. Journal of Environmental Management 86(3): 566-574.

[24] Fanelli G., Tescarollo P. and Testi A. (2006). Ecological indicators applied to urban and suburban floras. Ecological Indicators 6(2): 444-457. 